\title{
TERAPI DEPRESI DENGAN GAMELAN JAWA
}

\author{
Oleh : Warih Jatirahayu \\ Guru SMP Negeri 4 Sleman Yogyakarta
}

\section{Pendahuluan}

Menurut organisasi kesehatan dunia (WHO: world health organization) setiap tahun kian bertambah orang-orang yang mengalami depresi. Ada berbagai faktor penyebab depresi antara lain arus modernisasi dan globalisasi yang sulit terbendung, kompleksnya kebutuhan hidup, makin bertambahnya usia harapan hidup, perubahan sosial kultural yang semakin cepat, kenaikan kualitas dan kuantitas penyakit menahun dan penyakit tidak menular, penyalahgunaan zat dan obat adiktif, seperti alkohol, obat tidur dan penenang, perubahan gaya hidup, perkembangan ilmu pengetahuan dan teknologi yang begitu cepat.

Modernisasi, globalisasi, dan teknologi informasi menjadikan segala sesuatu berkembang begitu kompleks dan cepat. Era demikian menjadikan orang-orang mudah saling berinteraksi tanpa dibatasi ruang dan waktu. Interaksi manusia saling bertransaksi, tata nilai, ipteks, kebudayaan, gaya hidup, dan sebagainya. Apabila tuntutan manusia dapat terpenuhi, menimbulkan kebahagiaan. Sebaliknya, apabila manusia tidak dapat memenuhi tuntutan dalam kehidupannya mengakibatkan timbulnya permasalahan. Bertambahnya usia harapan hidup berarti bertambah pula kemungkinan mengalami permasalahan di hari tua, karena emosi positif rendah, kesadaran diri rendah, dorongan kuat untuk berbuat (Duberstein et.al, 2001:380) sementara kemampuan semakin berkurang atau terbatas.

Tuntutan yang tidak tercapai, ketidakmampuan menyesuaikan diri dengan perkembangan zaman, kebutuhan, gaya hidup, dapat mengakibatkan manusia merasa rendah diri, kecil, menyalahkan diri sendiri, berpikir negatif, tidak semangat, kehilangan nafsu makan, sulit tidur, dan sebagainya. Pada kondisi demikian, orang dapat dengan mudah mengalami stres atau mengalami kecemasan. Gejala depresi dapat bersifat parsial (sebagian dari gejala) atau mengalami gejala (kompleks). Semakin kompleks gejala depresi semakin kompleks pula depresi yang dialami seseorang. Bahkan ada kecenderungan bunuh diri.

Depresi merupakan suatu penyakit yang dapat merugikan diri sendiri, bahkan orang lain. Jika depresi tidak diikuti gejala aktivitas fisik yang "menggila" (tindakan di luar batas kewajaran), depresan akan orang bergantung pada orang lain atau membebani orang lain 
(minimal orang tua, saudara, atau keluarga). Jika depresan parah hingga diikuti perilaku "menggila", perilaku depresan akan membahayakan dirinya dan mengganggu serta membahayakan orang lain.

Depresan harus diselamatkan. Untuk menyelamatkan depresan, perlu dilakukan terapi. Terapi dilakukan agar depresan kembali normal, hidupnya tidak bergantung pada orang lain, memiliki semangat produktif, sehingga hidupnya berguna, berpikir positif. Tujuan akhir terapi bagi depresan adalah menjadikan dia manusia seutuhnya (the fully function person), yakni manusia yang berguna bagi orang lain atau memiliki kontribusi dalam kehidupan.

\section{Depresi: Karakteristik dan Jenis}

Secara awam depresi adalah suatu keadaan emosi yang menunjukkan perasaan susah, murung, sedih, tidak bahagia, dan tidak mempunyai semangat hidup. Hasil penelitian Retnowati (2001) menunjukkan bahwa pola pikir negatif sebagai sumber daya personal, terbukti sebagai mediator dan moderator dampak negatif menekan pada munculnya depresi. Depresan melakukan kesalahan berlogika, mempunyai pandangan negatif mengenai dirinya sendiri dan masa depannya. Orang depresi hanya melihat kesulitan dan kegagalan. Hal demikian menyebabkan suasana depresif, seperti hilang kemauan, menolak harapan, ketergantungan, bahkan yang parah ada keinginan untuk bunuh diri.

Maxmen yang dikutip oleh Martaniah (1989:1) mengklasifikasikan depresi adalah sebagai berikut: (1) Depresi endogenus. Depresi ini mengakibatkan depresan kehilangan nafsu makan, kehilangan berat badan, insomnia dan hipersomnia, kelambatan atau kelebihan aktivitas fisik, kehilangan nikmat dan kegairahan dalam berbagai aktivitas, kekurangan energi atau lelah, gangguan seksual, gangguan pencernaan, seperti mulut kering, mual, sembelit, bahkan diare. (2) Depresi reaktif. Depresi ini disebabkan oleh gejala psikososial, antara lain keadaan emosi yang menunjukkan perasaan susah, murung, sedih, tidak bahagia, dan tidak mempunyai semangat, anhedonia (perasaan yang tidak mampu untuk mengalami kesenangan dalam melakukan atau menjumpai kejadian yang pada umumnya dapat menyebabkan kesenangan), putus asa, distimia (suasana hati yang tidak menyenangkan), tertekan, disforia (kesedihan, marah, dan takut). (3) Depresi primer, yakni depresi yang disebabkan oleh faktor biologis atau psikososial tanpa didahului oleh penyakit sebelumnya. Kegagalan, keterhimpitan hidup, tekanan jiwa, dan sebagainya dapat 
menyebabkan depresi primer. (4) Depresi sekunder didahului oleh penyakit sebelumnya. Misal seseorang mengalami depresi karena mengalami penyakit menahun yang tidak kunjung sembuh. Penyakitnya telah menggerogoti fisik, harta, ketenteraman dan kebahagiaan keluarga, merasa tidak dapat membahagiakan keluarga malah menjadi beban, ia merasa tidak berguna. Semua memacu timbulnya depresi sekunder. (5) Depresi unipolar yang dilatarbelakangi oleh sejarah episode mania atau hipomania. Depresan memiliki sejarah mania atau hipomania yang sudah sekian lama (berepisode), misalnya kambuhan atau bergradasi (depresi bertingkat). Mania adalah tindakan motorik yang berlebihan, kasar, dan tidak terkontrol. Tindakan demikian dapat membahayakan diri sendiri dan orang lain. Hipomania adalah tidak ada hasrat untuk bertindak, seperti lumpuh kemauan, tidak semangat, malas, tidak mau bertindak, dan sebagainya. Depresan demikian menjadi bergantung pada orang lain, membebani orang lain, bahkan menyusahkan orang lain. (6) Depresi bipolar, tidak memiliki sejarah mania dan hipomania. Depresi sebagai akibat tekanan biologis atau kejiwaan, dan sosial. Akibat dari depresi bipolar dapat bersifat biologis dan psikososial, yang gejalanya telah disebutkan di atas. (7) Depresi psikotik adalah depresi parah. Keparahan depresi dapat diamati dari gejala biologis dan psikososial. Secara biologis, semakin parah depresi semakin tidak ada gairah hidup, lumpuh semangat, maag akut, mania, atau hipomania. Secara psikososial dapat diamati dari keadaannya, seperti sedih, murung, putus asa, menyalahkan diri sendiri, berpikir negatif, bahkan dapat menuju hasrat untuk mengakhiri hidupnya. (8) Depresi nerotik adalah depresi pada tahapan ringan. Pada depresi ringan, depresan juga mengalami gejala abnormal secara biologis/ psikomotorik maupun psikososial walaupun tarafnya tidak parah atau ringan. Depresan tidak melakukan hal yang membahayakan dirinya sendiri atau orang lain.

\section{Terapi Depresi dengan Mendengarkan Gamelan Jawa}

Depresi terjadi karena ketidakseimbangan antara harapan dan kenyataan. Keinginan atau cita-cita yang berlebihan (tidak sesuai dengan kemampuan) yang tidak tercapai dapat mengakibatkan depresi. Berdasarkan teori kognitif, depresi disebabkan oleh berpikir negatif, dikotomis, dan terbatas (Duberstein, 2001:1). Ini berarti depresi sangat dipengaruhi oleh pola pikir seseorang. Menurut Umar Kayam (1989) pola pikir seseorang dipengaruhi oleh tata nilai. Tata nilai berkaitan dengan sistem nilai. Sistem nilai merupakan eksistensi kebudayaan. Berdasarkan hal tersebut secara analogi dan logika terbalik, terapi depresi dapat didekati dengan pendekatan budaya. 
Terapi budaya untuk gangguan kejiwaan telah dilakukan oleh RSJ Soerojo Kota Magelang, Jawa Tengah, yakni dengan memperdengarkan dan melibatkan pasien dalam bentuk pagelaran seni tradisional seperti jatilan. Hasilnya cukup signifikan bagi pasien yang memiliki latar belakang budaya Jawa (http://promojatengbikk.com/). Ini membuktikan bahwa terapi budaya (yang disesuaikan dengan pola pikir dan tata nilai) dapat digunakan untuk terapi kejiwaan (termasuk di dalamnya depresi).

Ada beberapa alasan gamelan Jawa dapat digunakan sebagai terapi depresi.

1. Gamelan Jawa mampu mempengaruhi, menggerakkan alam sekitar. Dengan mendengarkan gamelan Jawa dapat tercipta atmosfir yang di kehendaki oleh irama gamelan ini. Sejak abad 5-6, masyarakat jawa mengenal alat musik gamelan. Gamelan dibuat sebagai alat musik pentatonis yang mampu menciptakan gelombang elektro magnetis.

2. Gamelan juga dipakai sebagai terapi jiwa pada manusia. Gamelan adalah alat musik tradisional Jawa. Gamelan semacam simponi atau orkestra ala barat, karena gamelan juga menggunakan banyak instrumen. Di Jepang pernah dilakukan penelitian, bahwa bayi dalam kandungan yang biasa diperdengarkan lagu-lagu simponi atau orkestra meningkatkan daya inteligensi. Ini membuktikan bahwa nilai rasa musikal dapat mempengaruhi pola pertumbuhan syaraf otak. Menurut Isa Multazam (2007) dari Fakultas Kedokteran UGM gamelan dapat digunakan untuk terapi gangguan kejiwaan (depresi psikososial). Gamelan Jawa kini telah dipakai sebagai salah satu bentuk pengobatan komplementer bagi pasien-pasien dengan gangguan kejiwaan pada beberapa rumah sakit di Inggris.

Terapi gamelan telah berhasil dalam meredakan emosi dan menstabilkan perasaan dari pasien gangguan kejiwaan. Terapi gamelan menciptakan suatu rasa kebersamaan diantara pasien, sebagai bentuk pemenuhan dukungan sosial yang bersifat emotional support. Alunan ketukan musik gamelan membuat pendengarnya dapat mengekspresikan perasaan dan menciptakan kebersamaan dalam memadukan ketukan-ketukan gamelan, sehingga tercipta ketentraman hati.

3. Gamelan di Eropa juga dikembangkan sebagai terapi. Di Paris sudah ada beberapa penjara yang mengembangkan program gamelan untuk terapi bagi penghuni penjara. "Penghuni penjara (Eropa), yang biasanya individualis dan tak mau mendengarkan orang, melalui gamelan bisa bekerja sama. Mereka menabuh demung, misalnya, harus menguping yang menabuh bonang dan sebagainya. Mereka jadi belajar hidup 
kolektif," kata Supanggah yang pada pementasan Megalitikum Kuantum dalam rangka ulang tahun ke-40 harian Kompas di Jakarta Convention Center, Jakarta, tanggal 29-30 Juni 2005 dalam tugas menggarap gamelan saat mengetengahkan Ketawang Puspowarno ciptaan Mangkunegara IV.

4. Di Eropa gamelan dipergunakan untuk menanamkan budi pekerti, menahan emosi dan keberingasan. "Teman saya (di Eropa) ada yang bisa menangis hanya karena bisa mengusung gamelan berdua. Mengusung bareng barangkali merupakan hal yang tidak luar biasa bagi kita. Tetapi di Eropa ternyata mengangkat berdua itu pun suatu kebahagiaan, yang tak terpikirkan di kita," kata Supanggah menambahkan. Keterbukaan gamelan tidak heran membuat musik Jawa ini begitu populer di Amerika, mulai dari Boston, Wesleyan, Yale, New York, yang menjadi pusat-pusat gamelan di East Coast (Pantai Timur) Amerika Serikat, sampai di West Coastmulai dari Vancouver (pemain gamelan bule di sini hebat-hebat) sampai Seattle, Berkeley, Santa Barbara, dan juga di University of California Los Angeles (UCLA). Gamelan di Inggris juga dikenal melalui program Good Vibrations. Program ini dibuat di penjara Top Security Prison Wakefield untuk mengatasi masalah kejiwaan dan perilaku manusia yang putus asa karena terjerat narkoba, kriminalitas dan psikologi berat. Dengan konsep berekspresi lewat musik gamelan yang mengutamakan kebersamaan, toleransi, kerjasama, dan pengendalian emosi, program ini telah berhasil dijalankan. Hingga saat ini telah lebih dari 14 penjara mengadopsi sistem ini. Walau dalam berbagai bidang prestasi Indonesia masih belum berkumandang, setidaknya dengan berkumandangnya gamelan diberbagai penjuru dunia mampu melantunkan tembang perdamaian di dunia (Harianto, 2007).

Gamelan dapat dikolaborasikan dengan terapi relaksasi. Relaksasi adalah suatu tindakan untuk membuat seseorang menjadi rileks (santai), indah, nyaman, dan tenteram secara kejiwaan. Depresi merupakan suatu keadaan yang tegang secara kejiwaan. Ketegangan jiwa (pemikiran) disebabkan oleh ketidakseimbangan antara harapan dan kenyataan. Untuk meregangkan ketegangan kejiwaan, perlu diciptakan situasi yang santai, kondisi yang menenangkan dan menyenangkan, dan suasana damai. Untuk menciptakan kondisi demikian, dapat diperdengarkan musik yang mengalun, mendayu, merdu, harmoni, sehingga mengendorkan urat saraf. Itulah sebabnya musik gamelan dikolaborasikan dengan Spa (Solus Per Aqua) dan relaksasi. 
Untuk mendukung suasana dan memotivasi relaksasi, musik gamelan dipilihkan yang berirama pelan (tempo pelan), mendayu, mengalun merdu, seperti Ladrang Sri Kaloka Slendro Manyura, Ketawang Kutut Manggung Slendro Manyura, Ketawang Sekar Teja Slendro Manyura, Ladrang Mugi Rahayu Slendro Manyura, Ladrang Sri Widada Pelog Barang, Ladrang Asmaradana Slendro Manyura. Terapi gamelan ini bertujuan (1) agar depresan hanya menikmati alunan musik saja. Jiwa, saraf, dan aliran darah mengalir lembut bagaikan musik terapi dan (2) depresan tidak memikirkan makna syair yang ada. Jika ada syair dikhawatirkan, depresan malah memikirkan isi syair sehingga tidak santai lagi. Diharapkan depresan hanya menikmati musik saja secara psikologis tanpa terganggu secara kognitif. sehingga depresan dapat rileks dan mengurangi beban depresi.

\section{Penutup}

Depresi adalah keadaan seseorang yang selalu mengembangkan berpikir negatif yang mengakibatkan seseorang berbuat mania atau hipomania. Perilaku mania dapat membahayakan diri sendiri dan orang lain. Sebaliknya, perilaku hipomania membuat seseorang bergantung pada orang lain yang dapat menyusahkan orang lain. Terapi depresi dapat dilakukan dengan mengembangkan berpikir positif melalui pendekatan budaya. Produk budaya Jawa yang dapat dijadikan alternatif terapi depresi adalah dengan mendengarkan gamelan yang dapat dipadukan dengan terapi yang lain, seperti Spa. Kepasrahan secara total membuat orang mengembangkan pola pikir positif. Pola pikir positif dapat menjadi terapi pikir bagi depresan. Sikap demikian dapat menjadi terapi bagi orang yang menderita depresi.

\section{Daftar Pustaka}

Harianto, Jimmy S.2007. Di Eropa Gamelan Diajarkan untuk Menanamkan Budi Pekerti. http://opensource.opencrack.or.id/

Kayam, Umar. 1989. “Depresi Tinjauan Sosio-budaya”. Simposium Penanggulangan Depresi dalam Era Modernisasi. Yogyakarta: UGM.

Martaniah, Sri Mulyani. 1989. "Depresi: Tinjaun Psikologis". Simposium Penanggulangan Depresi dalam Era Modernisasi. Yogyakarta: UGM. 
Retnowati, Sofia. 2001. Sumber Daya Pribadi dan Sosial Sebagai Mediator Dampak Kejadian Menekan Terhadap Munculnya Simtom Depresi pada Remaja. Dalam http://www.psikologi.ugm.ac.id.

RSJ Magelang Terapi Budaya Untuk Pasien. 2007. http://promojatengbikk.com/berita.php?id=2290 